|Hawasi Bin Arsam, Ahmad Munif Suratmaputra, Wendi Parwanto, Sadari

\title{
TAFSIR AYAT AL-SIYAM KARYA M. BASIUNI IMRAN, SAMBAS, KALIMANTAN BARAT: Studi Kritis Atas Genealogi Pemikiran dan Epistemologi Tafsir
}

\author{
Hawasi Bin Arsam ${ }^{1}$, Ahmad Munif Suratmaputra ${ }^{2}$, Wendi Parwanto ${ }^{3}$, Sadari $^{4}$ \\ arsamhawasi@gmail.com | amunifsp@gmail.com | \\ wendipurwanto01@gmail.com | arifahmikhan@gmail.com
}

\begin{abstract}
Abstrak
Riset tentang tafsir ke-nusantara-an atau ke-indonesia-an telah banyak dilakukan oleh para peneliti, namun penelitian yang fokus pada tafsir yang ada di Kalimantan Barat belum banyak dilakukan, terutama terkait naskah Tafsir Ayat Al-Siyam karya M. Basiuni Imran. Di sini, penulis tertarik untuk mengisi ruang tersebut dengan memfokuskan pada aspek genealogi (asal-usul) dan episteme (rancang bangun) tafsirnya. Karena itu, tentu riset ini berjenis kepustakaan dengan metode deskriptif-analitis serta genealogi dan epistemologi sebagai kerangka teori yang akan penulis pakai secara lentur. Penelitian ini menemukan bahwa genealogi pemikiran M. Basiuni Imran banyak tertambat pada pemikiran M. Rasyid Ridha serta literatur-literatur Timur Tengah. Adapun dari aras epistemologi, sumber tafsir M. Basiuni Imran banyak merujuk pada kitab-kitab tafsir terdahulu, hadis, dan tentunya al-Qur'an itu sendiri. Prinsip dan metode penafsiran yang digunakannya adalah prinsip deksripsi leksikal-linguistik, prinsip konektivitas dan relasi teks, dan prinsip ilustrasi sebagai penjelas penafsiran. Corak tafsirnya lebih pada adabi-ijtima'i dengan gaya ijmali. Validitas tafsirnya adalah pragmatis.
\end{abstract}

Kata Kunci: Tafsir al-Siyam; M. Basiuni Imran; Kalimantan

1 Dosen Institut Agama Islam Shalahuddin Al-Ayyubi (INISA) Yambun-Bekasi.

${ }^{2}$ Dosen Institut Ilmu al-Qur'an (IIQ) Jakarta.

${ }^{3}$ Dosen Institut Agama Islam Negeri (IAIN) Pontianak Kalinantan Barat.

4 Dosen Institut Agama Islam Shalahuddin Al-Ayyubi (INISA) Yambun-Bekasi. 


\section{A. Pendahuluan}

Pada rentang waktu antara abad ke-17 M sampai $20 \mathrm{M}$, Timur Tengah merupakan "magnet intelektual" bagi sejumlah pelajar dari Nusantara, termasuk yang berasal dari Sambas, Kalimantan Barat. $^{5}$ M. Basiuni Imran adalah salah satu contohnya. Sosok yang cukup fenomenal di lingkarannya pada abad ke-20 M ini-sebab pernah menanyakan langsung pada Rasyid Rida seputar mengapa masyarakat Muslim terbelakang hari ini dan umat lainnya maju, ${ }^{6}$ limadza ta akhkhar al-muslimun wa limadza taqaddama ghairuhum-boleh dibilang memiliki ketertarikan lebih pada studi al-Quran. Beberapa karangan tafsir sudah ia telurkan, salah satunya adalah tafsir Ayat al-Siyam. Secara fisik, tafsir tersebut masih berupa manuskrip. Bentuknya masih murni dari apa yang pernah ditulis Basiuni Imran. Dalam artian, naskah tafsirnya masih bebas dari hasil suntingan pihak mana pun, sehingga bagaimanapun ini akan lebih memudahkan penulis untuk melakukan pengamatan. Naskah tafsir Ayat alSiyam sementara ini masih tersimpan di Museum Tamaddun, Sambas, Kalimantan Barat.

Mendapatkan pengalaman interaksi dengan manuskrip di muka, penulis merasa tergoda untuk tidak saja menyituasikannya sebagai barang antik yang hanya layak dipajang atau dimuseumkan, tetapi juga mengamatinya hingga seseorang bisa mengetahui kebudayaan, peradaban, dinamika keilmuan, dan persilangan wacana seperti apa yang ada dalam naskah. Walhasil, penelitian ini mencoba untuk mendekati manuskrip tafsir tersebut langsung lewat pintu genealogi dan episteme. Banyak sisi dari tulisan ini akan banyak berhutang pada dua teori tersebut versi Foucault.

5 Azyumardi Azra, Jaringan Ulama Timur Tengah dan Kepulauan Nusantara Abad XVII \& XVIII (Jakarta: Kencana, 2007), xx-xxi.

6 Pertanyaan ini memotivasi Amir Syakib Arsalan untuk membukukannya dalam sebuah risalah yang dalam edisi Inggrisnya diberi judul Our Decline: Its Causes, diterbitkan pertama kali pada tahun 1944 di India, dan kembali diterbitkan di Malaysia pada tahun 2004. Dalam edisi Indonesianya diterjemahkan oleh Munawwar Chalil dengan judul Mengapa Kaum Muslimin Mundur (Jakarta: Bulan Bintang, 1954). 
Penelitian seputar tafsir Nusantara tidak bisa tidak usai banyak dilakukan oleh sejumlah peneliti. Mulai dari riset atas kitab Tafsir Tarjuman al-Mustafid karya Abdul al-Ra'uf alSingkili, Tafsir Marah Labid li Kasyfi Ma'ani al-Qur'an alMajid karya Nawawi Al-Bantani, Tafsir Al-Ibriz karangan Mustafa Bisri sampai Tafsir Raudhatuh al-Irfan KH. Ahmad Sanusi telah banyak dibidik dan menjadi bidang garapan, bahkan expertise banyak peneliti. Akan tetapi, yang fokus pada M. Basiuni Imran, apalagi tafsir Ayat al-Siyam, sejauh penelusuran penulis masih sangatlah jarang. Jadi, dengan alasan-alasan tersebut, penelitian ini penting untuk dilakukan.

\section{Sekilas Tentang Kerajaan Sambas}

Sebelum masuk pada inti pembahasan, bagian ini akan terlebih dulu memberikan gambaran umum tentang konteks tempat M. Basiuni Imran tumbuh dan berkembang. Ini nantinya penting untuk dibuat sebagai alas dalam melihat kecenderungan tafsir karya Imran. Adalah sebagi berikut.

Kerajaan Sambas merupakan bentuk lanjut dari kerajaan Hindu yang yang sudah ada di situ beberapa abad sebelumnya. Banyak pakar memperkirakan bahwa kerajaan Hindu berkuasa sejak abad ke-14 M sampai 16 M. Selama dua abad ini banyak perjumpaan budaya terjadi, di antaranya antara tradisi Hindu dan Islam. Pada abad ke-15 M tepatnya, ajaran Islam mulai masuk ke Sambas. Namun, karena pengaruh ajaran Hindu masih kuat, Sambas pada kisaran abad ini masih melekat dengan tradisi Hindu. Ajaran Islam tetap mendapatkan penerimaan dari masyarakat, tetapi sebatas di wilayah pesisir. ${ }^{7}$

Seiring berjalannya waktu serta perebutan ruang publik yang tidak sederhana, pada abad ke-17 M, kisahnya berbeda. Pada abad ini, etika-etika dasar yang ada dalam ajaran Islam rupanya lebih sesuai dengan kebutuhan masyarakat Sambas. Ajaran Islam menemukan momentum di samping semakin banyaknya agen yang cukup persuasif dan kontekstualis. Pada abad ini, Islam mulai menuju agama yang dominan di masyarakat Sambas.

${ }^{7}$ Risa, "Islam di Kerajaan Sambas Antara Abad XV-XVII : Studi Awal Tentang Islamisasi di Sambas", dalam jurnal Khatulistiwa, vol. 4, no. 2 (2014), 106. 
Petanda utama dari getaran ini adalah berdirinya kerajaan (Islam) Sambas, Kerajaan Alwatzikoebillah. ${ }^{8}$ Kerajaan ini berkuasa dari tahun 1630 sampai 1950 M. $^{9} \quad$ Selama masa kekuasaan tersebut, kerajaan Sambas dipimpin oleh lima belas (15) Sultan secara bergantian dan dua (2) orang Majlis Kesultanan dengan masa kejayaan pecah ketika berada di bawah kendali Sultan Muhammad Shafiuddin II. ${ }^{10}$

Kerajaan Islam Sambas terhitung sejak pemerintahan Sultan pertama, Muhammad Shafiuddin I sampai Sultan kedelapan, Sultan Muhammad Ali Shafiuddin, tidak pernah mengalami kegoncangan yang cukup berarti, termasuk dari kerajaan atau bangsa lain. Malah, pada rentang paruh awal abad ke-18 M sampai paruh pertama abad ke-19 M, kerajaan Sambas mendapatkan citra sebagai pusat peradaban sekaligus kerajaan terbesar di wilayah pesisir utara Kalimantan Barat.

${ }^{8}$ Pabali H. Musa, Sejarah Kesultanan Sambas Kalimantan Barat: Kajian Naskah Asal Raja-raja dan Silsilah Kerajaan Sambas (Pontianak: STAIN Press, 2003), 36.

${ }^{9}$ Dalam Pabali H. Musa, Sejarah Kesultanan Sambas, Kalimantan Barat, 35-36.

${ }^{10}$ Sultan Muhammad Tsafiuddin II, kerap disapa Raden Afifuddin adalah putra Sultan Abubakar Tadjudidin II dengan permaisurinya Ratu Sabar. Baginda dilahirkan pada subuh Kamis tanggal 3 Syawal $1257 \mathrm{H}$ atau 18 November $1841 \mathrm{M}$. Diangkat sebagai putra mahkota usia 7 tahun yaitu tanggal 17 Januari 1848 M dengan gelar Pengeran Adipati. Sewaktu di Batavia, Baginda tinggal di rumah Syarif AbdulKadir untuk diberi pendidikan oleh Belanda. Sementara ayahnya dipindahkan ke Cianjur. Setelah beberapa tahun di Batavia, Baginda dipindahkan ke Kabupaten Galuh yaitu di Ciamis. Pada tanggal 5 April 1861 M Baginda diangkat menjadi Sultan Muda, kemudian tanggal 6 Agustus 1866 M Baginda diangkat menjadi Sultan Sambas yang ke13 dengan gelar Sultan Muhammad Tsafiuddin II mengantikan Sultan Umar Kamaluddin yang telah menjadi wakil Sultan selama 19 tahun.Baginda mempunyai seorang permaisuri bernama Raden Khalijah binti Kesuma Ningrat dan seorang saksi bernama Enei Nauyah digelar Mas Sultan. Baginda memerintah negeri Sambas selama 56 tahun dan wafat pada tanggal 12 September 1924 M dalam usia 83 tahun. Jaelani, "Sultan Muhammad Syafiuddin II : Pemimpin Karismatik dari Ujung Utara Borneo Barat", dalam jurnal Khatulistiwa, vol. 4, no. 2, (2014), 128. 
Kisah ini berubah drastis ketika Belanda masuk pada akhir paruh pertama abad ke-19 M. Seperti biasanya, untuk mengikis kerajaan Sambas, Belanda tidak perlu secara langsung berhadapan dengannya. Belanda cukup dengan menginiasi berdirinya kerajaan lain, yang kali ini adalah kerajaan Pontianak, membesarkannya, dan lantas membuka celah untuk kedua kerajaan bersaing.

Sejarah menyebut bahwa, pada akhirnya, Kerajaan Sambas harus bertekuk di bawah dominasi Kerajaan Pontianak. ${ }^{11}$ Segala pencapaian kerajaan Sambas diambil-alih oleh Kerajaan Pontianak. ${ }^{12}$

Secara detail, sebenarnya pada tahun 1818, Belanda pernah mencoba merangsek masuk ke Kerajaan Sambas, tetapi Belanda hanya bisa sampai pada level mitra, bukan pihak yang dominan. Kemudian, baru pada tahun 1855 M, ketika pemerintahan dipegang oleh Sultan Umar Kamaluddin, Sultan ke12, yang dikenal sebagai Raden Tokok, ${ }^{13}$ Belanda sudah bisa ikut campur di urusan kebijakan, namun beberapa tahun selanjutnya, Belanda merasa penting untuk memiliki dominasi penuh. Akhirnya, Belanda semakin mendorong supaya Kerajaan Pontianak berkembang pesat dan mewujudkan keinginannya.

${ }^{11}$ Kerajaan Qadariyah Pontianak berdiri pada tanggal 14 Rajab 1185 H/ 23 Oktober $1771 \mathrm{M}$, yaitu pada masa kekuasaan Van Der Varra (17611775 M), gubernur jenderal VOC ke-29. Pendiri kesultanan ini adalah Syarif Abdurrahman AlKadrie, yang merupakan putra dari Habib Husein AlKadrie (ulama yang menyebarkan Islam di Pontianak yang berasal dari Arab). Kerajaan Pontianak berkuasa dari tahun 1771 sampai 1950, dengan dipimpin oleh delapan orang sultan, yaitu: Sultan Syarif Alkadrie (1771-1808 M), Sultan Syarif Kasim Alkadrie (1808-1819 M), Sultan Syarif Utsman Alkadrie (18191855 M), Sultan Syarif Hamid I Alkadrie (1855-1872 M), Sultan Syarif Yusuf Alkadrie (1872-1895 M), Sultan Syarif Muhammad Alkadrie (1895-1944 M), Sultan Syarif Thaha Alkadrie (1944-1945), dan Sultan Syarif Hamid II Alkadrie (1945-1950 M). Basuki Wibowo, "Otimalisasi Kraton Qadariyah dalam Pengembangan Pariwisata di Kota Pontianak Kalimantan Barat, dalam jurnal Edukasi, vol. 1, no. 1, (2014), 18-19.

${ }^{12}$ Puslitbang Kemenag RI, Ensiklopedi Pemuka Agama Nusantara, cet. I, jilid. 3 \& 6 (Jakarta: Puslitbang Kemenag RI, 2016), 1022.

${ }^{13}$ Puslitbang Kemenag RI, Ensiklopedi Pemuka Agama Nusantara, 1022. 
Tafsir Ayat ash-Shiyam karya M. Basiuni Imran, Sambas, Kalimantan Barat: Studi Kritis atas Genealogi Pemikiran dan Epistemologi Tafsir

\section{B. Genealogi Ulama: Posisi Muhammad Basiuni Imran dalam Jaringan Ulama Sambas dengan Ulama Timur Tengah}

Jaringan intelektual (intellectual network) antara ulama Sambas dan Timur Tengah perlu dieksplorasi. Ini penting dilakukan untuk melihat dua hal sekurangnya, yaitu bagaimana ide awal jaringan ulama Sambas dengan Timur Tengah terbentuk dan sejauh man ini berpengaruh pada keputusan Imran untuk Imran memilih Makkah dan Mesir sebagai tempat studinya. Ini yang pertama, sedangkan kedua lebih pada keterpengaruhan secara pemikiran antara Imran dan para ulama baik pada masa sebelumnya atau pun yang satu masa dengan Imran sebagai hasil dari proses transmisi serta transformasi intelektual yang ada kala itu.

Di antara ulama yang cukup representatif sebagai mata rantai penghubung antara ulama Nusantara dan Timur Tengah pada abad 18-19 adalah Syeikh Syamsuddin ${ }^{14}$ dan Syeikh Daud al-Fattani. ${ }^{15}$

${ }^{14}$ Syekh Syamsuddin adalah ulama besar Timur Tengah, seorang mursyid tarekat Qadiriyyah, yang dari beliau lah Syeikh Ahmad Khatib asSambasi meraih prestasi besar sebagai Syeikh Kamil Mukammil. Hawash Abdullah, Perkembangan Ilmu Tasawuf dan Tokoh-tokohnya di Nusantara (Surabaya: Al-Ikhlas, 1983), 179-180; Suriadi, "Pendidikan Sufistik Tarekat Qadiriyyah wa Naqsabandiyyah: Kajian Atas Pemikiran Syeikh Ahmad Khatib Sambas", dalam jurnal Khazanah, Vol. 15, No. 2 (2017), 259.

${ }^{15}$ Nama lengkap beliau adalah Syeikh Wan Daud b. Syeikh Wan Abdullah b. Syeikh Wan Idris Tok Wan Derasid Syeikh Wan Senik b. Tok Wan Abu Bakr b. Tok Kaya Pandak b. Andi (Faqih) Ali Datuk Maharajalela. Beliau lebih dikenali sebagai "Tok Syeikh Daud Fatani”. Beliau juga mendapat gelaran-gelaran lain seperti "al-'Alim al-"Allamah al-"Arif al-Rabbani”. Beliau dilahirkan di Kampung Kerisik. Dan tentang tahun kelahiran beliau, terdapat perbedaan di antara para peneliti, ada yang pendapat beliau dilahirkan pada $1133 \mathrm{H} / 1720 \mathrm{M}$, ada juga berpendapat pada tahun $1553 \mathrm{H} / 1740 \mathrm{M}$ atau tahun 1183H/1769M. Namun, yang lebih kuat bahwa Syeikh Daud al-Fattani dilahirkan pada tahun $1131 \mathrm{H} / 1718 \mathrm{M}$ dan beliau wafat di Ta'if pada tahun 1265H/1847 M. Syekh Daud al-Fattani adalah mursyid dalam tarekat Sammaniyyah dan Syadziliyyah, ada juga yang mengatakan mursyid tarekat Sattariyyah. Terlepas dari asumsi-asumsi tarekat mana beliau berkecimpung, jelasnya bahwa beliau adalah tokoh penting dalam ilmu tarekat. Hadenan dan Joni Tamkin, "Aspects of Economic Production in Malay Classical Literature According to Syeikh Daud Al-Fattani, dalam jurnal Al-Albab, Vol.1, No. 1 (2012), 4. 
Dalam rantai transmisi keilmuan, kedua nama tersebut tidak lain merupakan guru dari Ahmad Khatib al-Sambasi. ${ }^{16}$ Terinspirasi dari sejoli gurunya, Ahmad Khatib al-Sambasi mencoba untuk menginisiasi adanya jaringan khusus ulama Sambas dan berhasil. Murid Khatib al-Sambasi yang juga berasal dari Sambas dan potensial adalah H. Nuruddin. ${ }^{17}$ Pendeknya, jika dilingkup Nusantara ada Syaikh Syamsuddin dan Fattani, maka di level Sambas ada Khatib al-Sambasi. ${ }^{18}$ Pola yang dipakai keduanya dalam mendorong lahirnya jaringan tidak berbeda jauh. Adalah dengan perantara murid baik murid di Makkah atau pun ketika sudah kembali ke daerah, menginspirasi mereka tentang pentinganya sebuah jaringan, termasuk dalam kaitannya dengan transmisi serta transformasi keilmuan, dan kemudian menulis suatu karya yang bisa dibuat pegangan. ${ }^{19}$

${ }^{16}$ Puslitbang Kemenag RI, Ensiklopedi Pemuka Agama Nusantara,

${ }^{17}$ Puslitbang Kemenag RI, Ensiklopedi Pemuka Agama Nusantara, cet. I, jilid. 2 (A-B), 683.

18 Ahmad Khatib as-Sambasi dilahirkan di Kampung Asam, Sambas, Kalimantan Barat, pada tahun $1217 \mathrm{H} / 1802 \mathrm{M}$, dan meninggal pada tahun 1293 H/1875 M. Pada usia 19 tahun, beliau pergi ke Makkah untuk memperdalam ilmu pengetahuan agamanya. Selain berguru kepada sejumlah ulama di Makkah, seperti Syeikh Abd. Rasul al-Attar, Syeikh Abd. al-Hafidz 'Ajami dan sejumah ulama Makkah lainnya, beliau juga berguru kepada sejumlah ulama dari Nusantara yang bermukim di Makkah, seperti Abd. ashShamad al-Palimbani, M. Arsyad al-Banjari, Syeikh Daud b. Abdullah alFathani. Sedangkan murid-murid beliau di antaranya yaitu: Abd. Karim (Banten), Ahmad Hasbullah b. Muhammad (Madura), M. Ismail b. Abdurrahim (Bali), Abd. Latif b. Abd. al-Qadir as-Serawaki (Serawak), Syeikh Yasin (Kedah), Syeikh Nuruddin (Filipina) Syeikh Nuruddin (Sambas) dan sejumlah ulama lainnya. Dan Syeikh Ahmad Khatib as-Sambasi ini merupakan salah satu tokoh tarekat yang banyak melahirkan ulama-ulama dari Nusantara, yang akhirnya meneruskan ajaran beliau, khsusunya dalam wilayah tarekat. Lihat Nor Huda, Islam Nusantara : Sejarah Sosial Intelektual Islam di Indonesia (Yogyakarta: Ar-Ruzz Media, 2013), 304-305; Zamakhsyari Dhofier, Tradisi Pesantren: Studi Atas Pendangan Hidup Kyai (Jakarta: LP3ES, 1990), 90.

${ }^{19} \mathrm{Di}$ antara ulama yang mewakili abad ini adalah Syeikh Ahmad Khatib as-Sambasi (1802-1875 M), Syeikh Nawawi al-Bantani (1813-1897 M), Syeikh Ahmad Khatib al-Minangkabawi (1860-1916 M). Zulkifli, Sufism in Java: The Role of the Pesantren in the Maintenance of Sufism in Java (Laiden-Jakarta, INIS, 2002), 16. 
Dalam konteks Khatib al-Sambasi, karangannya yang berpengaruh adalah Fath al-Arifin. ${ }^{20}$ Karya inilah yang oleh banyak peneliti dilihat sebagai salah satu kitab induk dari tarekat Qadiriyyah al-Naqsabandiyyah dengan $\mathrm{H}$. Nuruddin sebagai corong yang potensial. ${ }^{21}$ Nuruddin merupakan salah satu siswa Khatib al-Sambasi ketika di Makkah dan ketika Nuruddin kembali ke Sambas, dia mendirikan sebuah surau untuk membagikan apa yang sudah diraupnya di Timur Tengah, termasuk ihwal spiritual — untuk tidak menyebut tarekat. ${ }^{22}$

Pada masa Khatib al-Sambasi, selain dirinya dan Nurrudin, ada pula satu nama yang tidak elok dilupakan, yaitu $\mathrm{H}$. Muhammad Saleh. Saleh lahir pada 1812 M di Sambas. Saleh juga termasuk dari jajaran ulama yang belajar di Makkah. Ia memilih untuk tinggal di Makkah untuk menimba ilmu selepas menunaikan haji.

Setelah dirasa cukup, Saleh pulang ke Sambas dan selang beberapa saat mendapatkan perhatian dari Sultan Sambas, yang waktu itu tidak lain adalah Sultan Muhammad Shafiuddin II, ${ }^{24}$ yang tertarik sama sekali dengan isu spiritual. Kebetulannya, Saleh pada waktu itu sudahlah memiliki satu karya menyoal spiritual, judulnya Aqidat al-Awwam, alhasil begitulah mengapa Sultan berkenan mengundang Saleh untuk menjadi guru spiritualnya. $^{25}$

${ }^{20}$ Pabali H. Musa, Sejarah Kesultanan Sambas Kalimantan Barat : Kajian Naskah Raja-raja dan Silsilah Raja Sambas, 5-6.

${ }^{21}$ Moh. Haitami Salim, dkk. Sejarah Kesultanan Sambas Kalimantan Barat, cet. 3 (Jakarta: Puslitbang Kemenag RI, 2011), 134.

${ }^{22}$ Moh. Haitami Salim, dkk. Sejarah Kesultanan Sambas Kalimantan Barat, 134.

${ }^{23}$ Moh. Haitami Salim, dkk. Sejarah Kesultanan Sambas Kalimantan Barat, 132-133.

${ }^{24}$ Diduga H. M. Shaleh menjadi guru spiritual Muhammad Syafiuddin II pada awal Sultan diangkat menjadi Raja, karena pada waktu itu terbukti dengan kebersamaan H. M. Shaleh dan M. Syafiuddin berangkat ke Batavia. Lihat Moh. Haitami Salim, dkk. Sejarah Kesultanan Sambas Kalimantan Barat, 134

${ }^{25}$ Pada bagian akhir dari kitab 'Aqidat al-'Awwam ini berisi syair ma'rifat tentang sifat dua puluh (sifat-sifat utama bagi Allah) dengan gaya bahasa puitis. Moh. Haitami Salim, dkk. Sejarah Kesultanan Sambas Kalimantan Barat, 132-133. 
Yang penting dicatat di sini adalah bahwa karya $\mathrm{H}$. Muhammad Saleh tersebut adalah hasil dari renungannya atas situasi sosial di masyarakatnya dan fath al-Arifin karangan Khatib al-Sambasi. Jadi, antara Khatib dan Saleh memiliki tautan sanad keilmuan yang lumayan erat. ${ }^{26}$

Sampai di sini, siapa pun bisa menengarai bahwa titik kait atau framing isu yang efektif dan dipakai Khatib al-Sambasi untuk membesarkan jaringan ulama Sambas adalah isu spiritual atau tarekat. Berporos pada pemikiran serta inisiasi dari Khatib al-Sambasi, termasuk kitab Fath al-Arifin, nama Sambas cukup populer di kalangan ulama se-Nusantara - tidak hanya Sambasdalam relasinya dengan isu tarekat. Agen-agen Khatib al-Sambasi seperti H. Nuruddin dan H. M. Saleh berperan penting di sini. Satu lagi: berkat kedekatan Sultan Shafiuddin II dengan H.M. Saleh, kerajaan Sambas pada masa itu memiliki kebijakan untuk mengirim putra-putra potensial daerahnya untuk belajar ke Timur Tengah, khusunya Makkah, Madinah, dan Mesir. ${ }^{27}$ Apa yang terjadi dalam cerita Imran tidak jauh-jauh dengan situasi ini.

\section{Jaringan Ulama Di Timur Tengah Dengan Kesultanan Sambas Pada Era 1293 H/1875 M Sampai 1331 H/1913 M}

Jika bagian sebelumnya fokus pada situasi pada masa Khatib al-Sambasi, maka bagian ini mencoba membangun gambaran yang ada di Sambas di masa setelahnya, yaitu antara 1875 dan 1913 M. Untuk memudahkan, penulis menyebut periode ini sebagai periode Sultan Shafiuddin II. ${ }^{28}$ Muhammad Basiuni Imran tergolong ulama yang berpengaruh pada periode ini. Pengaruh Imran lebih pada bagaimana ia menyuarakan pemikiran Rasyid Rida tentang pembaruan Islam. Ini bisa terjadi sebab kemewaktuan antara keduanya bertemu atau memiliki persinggungan sejarah.

${ }^{26}$ Muhammad Syafiuddin II memerintah dari Tahun 1866-1922 M. Jaelani, "Sultan Muhammad Syafiuddin II : Pemimpin Karismatik dari Ujung Utara Borneo Barat", dalam jurnal Khatulistiwa, vol. 4, no. 2, 2014, 135.

${ }^{27}$ Pabali H. Musa, Sejarah Kesultanan Sambas Kalimantan Barat : Kajian Naskah Raja-raja dan Silsilah Raja Sambas, 5-6.

${ }^{28}$ Muhammad Syafiuddin II memerintah dari Tahun 1866-1922 M. Jaelani, "Sultan Muhammad Syafiuddin II: Pemimpin Karismatik dari Ujung Utara Borneo Barat", 137. 
Imran hidup dan berproses di masa ketika Rida sedang naik daun di Mesir. Itu pun dilengkapi dengan Imran yang memiliki kesempatan langsung untuk menimba ilmu dari Rida di Mesir. ${ }^{29}$ Ada dua poin paling tidak yang paling mengena dari Rida buat Imran dan selalu dipegang untuk disebarkan ke lingkaran Imran di Sambas, yakni ketidakefektifan taklid dan pentingnya untuk sedikit mengurangi hal-hal berbau tarekat. Dua hal ini penting, menurut Rida, ${ }^{30}$ karena tanpa mereka, Islam sampai kapan pun hanya akan menjadi kebudayaan yang terbelakang. ${ }^{31}$

Ide reformis Islam yang dikoarkan Rida atau Abduh ini ternyata begitu berpengaruh di benak masyarakat Islam abad 20 M, termasuk Nusantara dan Sambas. Hal ini bukan tanpa alasan. Di samping sebab ide yang dibawakan beriringan sama sekali dengan logika dasar pikiran manusia, ini juga ada hubungannya dengan perantara yang dipakai. Rida, dalam menyebarkan pemikirannya, mengoptimalkan media yang sedang marak kala itu, yaitu majalah. Lewat majalah, Rida berasumsi bahwa ide reformis Islam tersebut bisa dinikmati oleh masyarakat dalam jangkauan yang lebih luas dan ternyata apa yang dibayangkan Rida benar. Banyak ulama Nusantara yang belajar ke Timur Tengah dan mendapat akses majalah tersebut merasa terbantu dengan adanya majalah al-Manar. ${ }^{32}$

${ }^{29}$ Muhammad Rasyid b. Ali Ridha b. Syamsuddin b. Baha'uddin AlQalmuni Al-Husaini. Lahir di Suriah Utsmaniyah, 23 September 1865/18 Oktober 1865 dan wafat di Mesir, 22 Agustus 1935. dikenal sebagai Rasyid Ridha) adalah seorang intelektual muslim dari Suriah yang mengembangkan gagasan modernisme Islam yang awalnya digagas oleh Jamaluddin al-Afghani dan Muhammad Abduh. Arthur Goldscmidt, Biografical Dictionary of Modern Egypt (London: Lynne Rienner Publisher, 2000), 166.

${ }^{30}$ Muhammad Yusran Asmuni, Pengantar Studi Pemikiran dan Gerakan Pembaharuan dalam Dunia Islam (Surabaya: al-Ikhlas, 1994), 85.

${ }^{31}$ Harun Nasution, Pembaharuan Dalam Islam (Jakarta: Bulan Bintang, 1986), 70.

32 Hamid Enayat, Modern Islamic Political Thought (London: Mc Millan, 1982), 69. 
Basiuni Imran tidak lain merupakan salah satu ulama yang merasakan kemudahan tersebut. Dari adanya majalah al-Manar banyak persoalan di Nusantara bisa lebih mudah diselesaikan dan di waktu bersamaan ini pulalah yang semakin memupuk jaringan ulama nusantara, ${ }^{33}$ tidak terkecuali Sambas. Dengan bahasa lain, posisi ide reformis Rida dan majalah al-Manar di sini bukan saja sebagai ide itu sendiri tapi juga sebagai jembatan untuk memudahkan para ulama Nusantara bertemu dalam satu wadah yang disebut sebagai jaringan ulama Nusantara. ${ }^{34}$

Jika ditarik sedikit ke belakang, ketika Imran masih menimba Ilmu di Mesir, interaksi yang terjalin antaranya dan Rida tidak saja tentang majalah al-Manar, tetapi juga interaksi tanya-jawab. Salah satu yang pernah melempar pertanyaan ke Rida tentang faktor kemunduran Islam adalah Imran. Imran dengan penasaran bertanya pada Rida seperti ini, "Limaza ta`akhkhara al-muslimun wa limaza taqaddama ghairuhum?" Dalam potret situas ini, Rida lalu mempersilahkan Amir Syakib Arsalan untuk merespons kegelisahan Imran. $^{35}$ Sebagai tambahan, yang menarik di sini dalam kaitannya dengan fokus artikel adalah konteks yang ada. Kajian tempat Imran bertanya adalah kajian seputar tafsir al-Qur'an. Jadi, ketika Imran bernai melemparkan pertanyaan dalam lingkar studi Quran tersebut, maka itu cukup menunjukkan betapa Imran tertarik dengan isu alQur'an pada sisi dan pada sisi lainnya menandakan betapa karya tafsirnya pentin untuk digali lebih mendetail.

${ }^{33}$ Oman Fathurahman, Jaringan Ulama: Pembaharuan dan Rekonsiliasi dan Tradisi Intelektual di Dunia Melayu-Indonesia, dalam jurnal Studia Islamika, vol. 11, no. 2, (2004), 365.

${ }^{34}$ Lihat bada bagian "introduction" dalam buku Our Decline: And Its Causes by Amir Syakib Arsalan diterjemahkan oleh Shakoor (Lahore: Muhammad Ashraf Publisher, 1944), XI.

${ }^{35}$ Pertanyaan ini memotivasi Amir Syakib Arsalan untuk membukukannya dalam sebuah risalah yang dalam edisi Inggrisnya diberi judul Our Decline : Its Causes, diterbitkan pertama kali pada tahun 1944 di India, dan kembali diterbitkan di Malaysia pada tahun 2004. Dalam edisi Indonesianya diterjemahkan oleh Munawwar Chalil dengan judul Mengapa Kaum Muslimin Mundur (Jakarta: Bulan Bintang, 1954), juga dicetak oleh Pustaka Al-Kautsar, 2013. 
Masih dalam periode ini, selain Imran ada beberapa nama lain yang juga sempat mengenyam pendidikan di Mesir dan belajar langsung ke Rasyid Rida, antara lain Abdurrahman Hamid, Saleh Arif, Ahmad Fauzi Imran (adik kandung Basiuni Imran), dan Ahmad Su'ud. Mereka masuk dalam jaringan ulama Sambas. Untuk Abdurrahman Hamid, selepas belajar di Mesir, ia sempat menjadi penghulu kerajaan, menjadi Imam Besar di Masjid Besar Kesultanan, dan mengajar di Madrasah Sultaniyyah sekaligus sekolah Tarbiyatul Islam. ${ }^{36}$

Adapun tiga terakhir, mereka tidak saja usai menimba ilmu dari Universitas al-Azhar, tetapi juga Madrasah Da'wah wa al-Irsyad, lingkar studi yang didirikan sendiri oleh Rasyid Rida. ${ }^{37}$ Tidak banyak ditemukan riwayat lengkap tentang kiprah dan ajaran ulama-ulama pada periode ini di wilayah Sambas, kecuali Muhammad Basiuni Imran. Ahmad Fauzi Imran, ia pernah diangkat oleh Muhammad Basiuni Imran sebagai kepala Madrasah Sulthaniyyah, sedangkan Ahmad Su'ud, ia pernah menjabat sebagai penghulu Mahkamah Syariah, di wilayah Singkawang. ${ }^{38}$

Selain mereka ada banyak nama lain yang pernah pula belajar ke Timur Tengah, namun informasinya samar-samar. Adalah H. Abdul Aziz, untuk menyebut yang pertama. Aziz pernah belajar di Madinah dan sepulangnya dari sana, ia diangkat oleh Sultan Syafiuddin II sebagai salah satu di antara Imam Masjid Jami' Sambas. Ia pernah pula menjabat sebagai penghulu kerajaan. ${ }^{39}$ Kedua adalah $\mathrm{H}$. Murtadho yang pernah studi ke Makkah dan diangkat menjadi khatib pada masa Sultan Syafiuddin oleh Basiuni Imran. Murtadho juga bernasib sama dengan Aziz dalam hal menjadi penghulu. ${ }^{40}$

${ }^{36}$ Moh. Haitami Salim, dkk. Sejarah Kesultanan Sambas Kalimantan Barat, cet. 3 (Jakarta: Puslitbang Kemenag RI, 2011), 136

${ }^{37}$ G. F. Pijper tentang keterangan biografi beliau. Lihat G. F. Pijper, Beberapa Studi tentang Sejarah Islam di Indonesia 1900-1950, terj. (Jakarta: UI Press, 1985), 144.

38 Pada waktu itu Singkawang masih tergabung dalam kekuasaan Kerajaan Sambas, 137

${ }^{39}$ Moh. Haitami Salim, dkk. Sejarah Kesultanan Sambas Kalimantan Barat, 137.

${ }^{40}$ Tim Penelitian dan Penulisan Sejarah Sambas, Kabupaten Sambas: Sejarah Kesultanan dan Kepemerintahan Daerah (Pontianak: Taurus, t.th), 90. 
Ketiga yakni Muhammad Djabir. Djabir tidak lain adalah paman dari Basiuni Imran. Djabir sempat mengenyam pendidikan di Makkah dan memiliki satu karangan dengan judul Risalah alHajj yang selesai ditulis pada 12 Rabi'ul Awwal $1331 \mathrm{H}^{41}$ Identik dengan Djabir adalah nama keempat, H. Ma'az Imran, adiknya Basiuni Imran. Pada masa itu, ia diangkat sebagai penghulu di Tebas, Sambas. ${ }^{42}$ Kelima yakni H. Asip Hamid yang juga menyelesaikan studi di Makkah dan lalu menjadi guru agama di Madrasah Sultaniyyah, Sambas. ${ }^{43}$

Sisanya yaitu H. Daeng Hadran, berasal dari pasar Melayu Sambas, pernah belajar di Makkah dan termasuk seorang huffadz al-Qur'an. ${ }^{44} \mathrm{H}$. Mi'raj Djabir, dari kampung Tanjung Rasau, Sambas, pernah pernah belajar di Makkah, dan pernah menjabat sebagai penghulu dan khatib di wilayah Bengkayang. ${ }^{45} \mathrm{H}$. Abbas, beliau pernah bermukin di Makkah bersama H. Arif selama 13 tahun, dan pernah menjabat sebagai penghulu di daerah Sentebang, Jawai, Sambas. ${ }^{46}$

Dari semua itu, bisa disimpulkan bahwa generasi kedua ulama Sambas banyak diposisikan oleh Sultan sebagi penghulu atau pemimpin - jika memakai arti pada masa itu-dari banyak daerah di bawah kekuasaan Kerajaan Sambas. Tugas utama penghulu adalah memberi fatwa. Fatwa atas berbagai persoalan yang sedang dihadapi masyarakat dan di antaranya adalah dengan mengarang kitab fikih sebagai pedoman dan acauan kepemimpinannya. ${ }^{47}$ Tidak banyak ditemukan keterangan tentang kiprah, ajaran atau kitab yang mereka tulis pada fase ini, kecuali Muhammad Basiuni Imran dan satu kitab yang ditulis oleh H. Muhammad Djabir yaitu kitab Risalah al-Hajj.

${ }^{41}$ Moh. Haitami Salim, dkk. Sejarah Kesultanan Sambas Kalimantan Barat, 135.

${ }^{42}$ Moh. Haitami Salim, dkk. Sejarah Kesultanan Sambas Kalimantan Barat, 137.

${ }^{43}$ Moh. Haitami Salim, dkk. Sejarah Kesultanan Sambas Kalimantan Barat, 137.

${ }^{44}$ Moh. Haitami Salim, dkk. Sejarah Kesultanan Sambas Kalimantan Barat, 138.

${ }^{45}$ Tim Penelitian dan Penulisan Sejarah Sambas, Kabupaten Sambas : Sejarah Kesultanan dan Kepemerintahan Daerah, 90.

${ }^{46}$ Moh. Haitami Salim, dkk. Sejarah Kesultanan Sambas Kalimantan Barat, 139-140.

${ }^{47}$ Islah Gusmian, "Tafsir Al-Qur'an di Indonseia: Sejarah dan Dinamika", dalam jurnal Nun, vol. 1, no. 1, (2015), 4. 
Dari penamaan kitab terlihat bahwa kitab ini adalah kitab fikih yang membahas tentang permasalahan seputar ibadah haji. Minimnya informasi serta keterangan tentang ajaran dan literatur ulama pada fase ini kemungkinan dipengaruhi oleh dua hal.

Pertama, para ulama fase ini masih merujuk atau menginduk kepada beberapa kitab atau ajaran yang ditelurkan oleh para ulama senior sebelumnya seperti ajaran tarekat syeikh Ahmad Khatib as-Sambasi, yang dibawa oleh H. Nuruddin, kemudian yang diajarkan pula oleh H. Muhammad Shaleh. Karena ajaran syeikh Ahmad Khatib as-Sambasi ini cukup hidup dalam realitas masyarakat Sambas pada waktu itu. ${ }^{48}$

Kedua, bisa juga ini disebabkan oleh pengaruh dari Basiuni Imran yang terlalu membayang-bayangi ulama lain semasanya. Adanya bekas dari bayang-bayang tersebut adalah dengan disematkannya gelar "Maharaja Imam" buat Imran oleh Sultan. Dengan ungkapan lain, ketika para ulama mendapati ada satu sosok yang terlalu dibanggakan sedemikian rupa, mereka merasa sia-sia untuk sekadar menulis karangan. ${ }^{49}$

\section{1) Potret Sosio-Historis Muhammad Basiuni Imran}

Muhammad Basiuni lahir pada 25 Dzulhijjah 1302 H/16 Oktober 1885 M di Sambas, Kalimantan Barat, Indonesia. Ia menutup mata untuk terakhir kalinya pada pada 29 Rajab 1396 H/26 Juli 1976 M dan dimakamkan di Sambas. Muhammad Basiuni Imran merupakan putra dari Haji Muhammad Arif, cucu Haji Imam Nurudin bin Imam Mustafa. Ia ditinggal wafat oleh ibunya, Sa'mi, saat masih belia dan kemudian diasuh oleh ibu tirinya Badriyah. M. Basiuni Imran merupakan adik dari Haji Ahmad Fauzi Imran.

${ }^{48}$ Khairul Fuad, "Meretas Sastra Sufistik Kalimantan Barat Pramodern dan Modern", dalam jurnal Analisa, Vol. 19, No. 1, (2012), 58.

${ }^{49}$ Machrus Effendy, Riwayat Hidup dan Perjuangan Maharaja Imam Sambas (Jakarta: PT. Dian Kemilau, 1995), 29-30. 
Pada tanggal 8 Rajab 1326 H/16 Agustus 1908 M, Imran menikah dengan Muznah, putri dari Imam Hamid, Sambas. Sekitar dua tahun setelah menikah, 22 Muharram 1328 H/ 3 Februari 1910 M, keluarga kecil ini dikarunia seorang putri cantik nan jelita. Namanya Wahajjah. ${ }^{50}$

Muhammad Basiuni Imran merupakan seorang qadhi, mufti dan ulama besar yang sangat kritis dan reformis. Pemikirannya telah menjadi pertimbangan tersendiri buat dunia Islam pada abad ke-20 dengan pertanyaan yang ia ajukan kepada Rasyid Rida, sebagaimana usai dijelaskan sebelumnya. Beliau juga memberikan inspirasi kepada negara-negara terjajah di seluruh dunia untuk membebaskan diri dari belenggu penjajahan. Muhammad Basiuni Imran adalah pewaris terakhir gelar Maharaja Imam (gelar tertinggi urusan Agama) di Kesultanan Melayu Sambas. Sambas pada waktu itu adalah sebuah kerajaan Islam yang terdapat di bagian utara pulau Kalimantan Barat, Indonesia. ${ }^{51}$

\section{2) Historisitas Perjalanan Studi}

Pada usia 6-7 tahun, Muhammad Basiuni Imran mulai bersentuhan dengan dunia pendidikan, baik dunia pendidikan formal dan pendidikan informal. Dalam pendidikan formal, Muhammad Basiuni Imran dimasukkan oleh sang ayah di Sekolah Rakyat (volksschool) di tanah kelahirannya, Sambas. Adapun dalam pendidikan keagamaan (informal) seperti bacatulis al-Qur'an dan nahu saraf, ia dibimbing langsung oleh sang ayah. Sang ayah menjadikan kitab al-Jurumiyyah dan Kailani dalam mengajarkan nahu saraf. ${ }^{52}$

${ }^{50}$ Wendi Parwanto, "Struktur Epistemologi Naskah Tafsir Surat AlFatihah Karya Muhammad Basiuni Imran, Sambas, Kalimantan Barat", Jurnal At-Tibyan, vol. 4, no. 1, 2019, 145-146; baca juga keterangan biografi Muhammmad Basiuni Imran dalam G. F. Pijper, Beberapa Studi tentang Sejarah Islam di Indonesia 1900-1950, terj. (Jakarta: UI Press, 1985), 134.

${ }^{51}$ Wendi Parwanto, "Struktur Epistemologi Naskah Tafsir Surat AlFatihah Karya Muhammad Basiuni Imran, Sambas, Kalimantan Barat", 146; Puslitbang Kemenag RI, Ensiklopedi Pemuka Agama Nusantara, 1021. 1900-1950, 142.

${ }^{52}$ G. F. Pijper, Beberapa Studi tentang Sejarah Islam di Indonesia 
Terkait pendidikan formalnya, tidak ditemukan informasi lebih lanjut tentang berapa lama Muhammad Basiuni Imran melakukan studi dalam pendidikan formal. ${ }^{53}$ Namun menurut A. Muis Ismail, pendidikan formal yang ditempuh oleh Muhammad Basiuni Imran adalah selama dua tahun, sedangkan informalnya menghabiskan nyaris 10 tahun. ${ }^{54}$

Pada 1319 H/1901 M, ketika Muhammad Basiuni Imran berusia 17 tahun, ia dikirim ke Makkah untuk menunaikan ibadah haji. Ini ia lakukan sekaligus dengan niat untuk menuntut ilmu, sehingga tempo ia menetap di Makkah cukup lama. Selama di sana, Muhammad Basiuni Imran memperlajari beberapa disiplin keilmuan antara lain pendalaman kembali nahu (syntax), saraf (morphology) dan fikih (Islamic jurisprudence). Di Makkah, ia juga berkesempatan untuk bersua dengan beberapa ulama dari berbagai daerah, termasuk Nusantara. Mereka adalah Tuan Guru Umar Sumbawa, Tuan Guru Usman Selawak, Ahmad Khatib Minangkabau, Ahmad al-Fattani, Usman al-Funtiani, dan Ali Maliki. ${ }^{55}$ Untuk nama yang terakhir, ia menimba isu-isu yang lebih kompleks dalam bahasa Arab dan kebudayaannya seperti ma'ani (semantika), badi' (stilistika), bayan, logika, usul fiqh, tafsir, dan teologi. Total jendral, Imran menghabiskan lima tahun masa studi di Makkah: dari 1901-1906 M. ${ }^{56}$

Sekembalinya dari Makkah, Imran langsung mendapatkan tempat untuk mengajar di salah satu lingkaran pendidikan di Sambas. Di sela kesibukannya mengajar ia menyempatkan untuk membaca majalah al-Manar dari Mesir. Ia sudah berlangganan, meski belum pernah ke Mesir, sehingga bisa rutin merenungi setiap edisinya. Selain itu, ia juga mengimbangi bacaannya dengan kitab-kitab lainnya dari Timur Tengah, hingga akhirnya, dari segenap bacaannya tersebut, Imran menemukan secercah pencerahan dari apa itu yang disebut Rida sebagai pemurnian ajaran Islam. Barat, 109.

${ }^{53}$ Moh. Haitami Salim, dkk. Sejarah Kesultanan Sambas Kalimantan

${ }^{54}$ Wendi Parwanto, "Struktur Epistemologi Naskah Tafsir Surat AlFatihah Karya Muhammad Basiuni Imran, Sambas, Kalimantan Barat", 148. Nusantara.. 1022

Puslitbang Kemenag RI, Ensiklopedi Pemuka Agama

${ }^{56}$ Wendi Parwanto, "Struktur Epistemologi Naskah Tafsir Surat AlFatihah Karya Muhammad Basiuni Imran, Sambas, Kalimantan Barat", 149 ; G. F. Pijper, Beberapa Studi tentang Sejarah Islam di Indonesia 1900-1950, 142-143. 
Maksud dari pemurnian ini lebih pada bagaimana seseorang penting untuk tidak menggantungkan pemahamannya terhadap apa pun kecuali al-Qur'an dan as-Sunah. Itu pun sunah yang dimaksud di sini bukan sembarang hadis atau bukan hadis itu sendiri melainkan memiliki rancang bangunnya sendiri yang tidak sederhana. Imran begitu terpengaruh oleh Rida di level ini. $^{57}$

Keterpengaruhan di muka tidak saja mewujud kegelisahan pikiran yang teramat menganggu, tetapi juga sampai pada titik tempat Imran begitu ingin pergi ke Mesir, melanjutkan studinya dan berjumpa langsung dengan Rasyid Rida. ${ }^{58}$ Imran pun kerap mengirim surat kepada majalah al-Manar, membicarakan kegelisahannya itu. Selang beberapa saat dari keinginannya yang membuncah tersebut, akhirnya Imran mendapat kesempatan untuk ke Mesir.

Pada 1910, bersama kakaknya, Ahmad Fauzi Imran, dan temannya, Ahmad Su'ud, Imran melawat ke Mesir. Mereka menumpang kapal Prancis yang akan melewati terusan Suez via Singapura. Sesampainya di Mesir, barangkali karena intensitas Imran mengirim surat ke redaksi majalah al-Manar, ia mendapatkan sambutan langsung dari Salih Rida, saudara dari Rasyid Rida. Mereka diajak menginap untuk sementara di kediaman Rida. Imran memanfaatkan sama sekali momentum ini, sehingga ia banyak bertanya kepada Rida, termasuk tentang apakah kemampuan bahasa Arab Imran sudah cukup. Rida menanggapi bahwa, diamati dari surat-surat Imran, kemampuan bahasa Arab Imran sudah cukup. ${ }^{59}$

57 Muis Ismail, Mengenal Muhammad Basiuni Imran (Maharaja Sambas). Laporan hasil penelitian (Pontianak: FISIP Universitas Tanjungpura, 1993), 143; Moh. Haitami Salim, dkk. Sejarah Kesultanan Sambas Kalimantan Barat, 110.

${ }^{58}$ Wendi Parwanto, "Struktur Epistemologi Naskah Tafsir Surat AlFatihah Karya Muhammad Basiuni Imran, Sambas, Kalimantan Barat”, 149.

${ }^{59}$ Wendi Parwanto, "Struktur Epistemologi Naskah Tafsir Surat AlFatihah Karya Muhammad Basiuni Imran, Sambas, Kalimantan Barat”, 149. 
Selama di Mesir, mereka mendapatkan kesempatan untuk menimba ilmu di Universitas al-Azhar selama enam bulan. Mereka bertemu dengan pelajar-pelajar lainnya dari Nusantara. Mereka terlibat banyak obrolan seputar Nusantara, Islam, dan penjajahan. Sampai akhirnya, ketika menginjak bulan ketujuh, mereka diboyong ke lingkar studi baru yang didirikan oleh Rida sendiri di Manyal, Kairo lama. ${ }^{60}$ Lingkar studi tersebut yakni Dar al-Da'wah wa al-Irsyad. Di sini, mereka mendapatkan isu tambahan seputar al-Qur'an dan teologi dan dibimbing langsung oleh Rida. ${ }^{61}$

Pada kisaran bulan Juli-Agustus 1913, Imran mendapatkan kabar bahwa ayahnya sakit keras. Imran disuruh kembali ke Sambas dan betapa pun, akhirnya masa studi Imran di Mesir berakhir. Tahun 1913 Imran kembali ke Nusantara dan ayahnya meninggal pada 25 Agustus 1913. Akan tetapi, lagi-lagi, ini bukan simtom kematian daya belajar serta ketertarikan Imran atas pemikiran Rida. Di rumah, Imran masih menjalin interaksi dengan Rida melalui redaksi majalah al-Manar. ${ }^{62}$

${ }^{60}$ Wendi Parwanto, "Struktur Epistemologi Naskah Tafsir Surat AlFatihah Karya Muhammad Basiuni Imran, Sambas, Kalimantan Barat", 149; Luqman Abdul Jabbar, "Tafsir Al-Qur'an Pertama di Kalimantan Barat (Studi Naskah Kuno Tafsir Surat Tujuh Karya Maharaja Imam Kerajaan Sambas 1883-1976 M)", dalam jurnal Khatulistiwa : Journal of Islamic Studies, vol. 5, no. $1,2015,108$.

${ }^{61}$ Wendi Parwanto, "Struktur Epistemologi Naskah Tafsir Surat AlFatihah Karya Muhammad Basiuni Imran, Sambas, Kalimantan Barat", 150.

${ }^{62}$ Muhammad Basiuni Imran mengungkapkan : "Segala puji bagi Allah! Walaupun saya telah meninggalkan guru-guru saya, juga telah meninggalkan bangku sekolah di Dar ad-Dakwah wa al-Isyad, saya tetap mendalami kitab-kitab fikih madzhab Syafi'i, kitab-kitab madzhab lain. kitabkitab tafsir al-Qur`an dan hadis, terutama tafsir al-Manar dan majalah alManar, dan juga kitab-kitab lain tentang bermacam-macam ilmu pengetahuan. Untuk meningkatkan kemampuan saya, maka saya pun melatih diri dengan menulis kitab-kitab atau risalah-risalah dalam bahasa Indonesia (maksudnya : bahasa Melayu), dan bahasa Arab, juga dengan mengajukan pertanyaanpertanyaan tentang soal-soal agama, lewat surat kepada shahih al-Manar (maksudnya Muhamamd Rasyid Ridha), waktu beliau masih hidup". Lihat Wendi Parwanto, "Struktur Epistemologi Naskah Tafsir Surat Al-Fatihah Karya Muhammad Basiuni Imran, Sambas, Kalimantan Barat", 150. 


\section{3) Deskripsi Karya-karya}

Karya-karya Basiuni Imran bisa penulis petakan menjadi empat yaitu bidang fikih, bidang sejarah, tafsir, dan akidah-adab. Pertama mencakup kitab al-Jana iz, al-Tadzkirat Badi'ah fi Ahkam al-Jum'ah, Dlau al-Mishbah fi Fasakh al-Nikah, Husn alJawab 'an Isbat al-Ahillah bi al-Hisab, Manhal al-Gharibin fi Iqamat al-Jumu'ah bi dun al-Arba'in, Risalah Cahaya Suluh, dan beberapa lainnya.

Kedua memuat buku Zikr Maulid al-Nabawi, Khulashah Sirah al-Muhammadiyyah, dan Nur al-Siraj fi Qissat al-Isra` wa al-Mi'raj. Ketiga terdiri dari Tafsir Tujuh Surat (surat al-Fatihah, al-'Asr, al-Kautsar, al-Kafirun, al-Ikhlas, al-Falaq dan al-Nas) dan Tafsir Ayat Al-Siyam (Tafsir Tentang Hukum Puasa). Terakhir mencakup Durus al-Tauhid, Bidayat at-Tauhid fi ' Ilm at-Tauhid, dan Irsyad al-Ghilman fi Adab Tilawat al-Qur`an. ${ }^{63}$

${ }^{63}$ Menurut G.F. Pijper, terhitung ada sebelas karya yang ditulis oleh Muhammad Basiuni Imran, dua ditulis dengan bahasa Arab, selebihnya ditulis dengan bahasa Melayu. Sedangkan menurut keterangan Moh. Haitami Salim, dkk. bahwa karya yang ditulis oleh Muhammad Basiuni Imran lebih dari sebelas tulisan, mulai dari yang sudah dicetak/terbit maupun yang masih dalam bentuk manuskrip/naskah. Oleh kerena itu, boleh jadi yang dihitung oleh Pijper adalah karya Muhammad Basiuni Imran yang sudah dicetak. Sedangkan yang dikumpulkan oleh Moh. Haitam Salim, dkk. adalah karya Muhamamd Basiuni Imran secara keseluruhan. Wendi Parwanto, "Struktur Epistemologi Naskah Tafsir Surat Al-Fatihah Karya Muhammad Basiuni Imran, Sambas, Kalimantan Barat", 150-151: Moh. Haitami Salim, dkk. Sejarah Kesultanan Sambas Kalimantan Barat (Jakarta: Puslitbang Kemenag RI, 2011), 114-132 bandingkan dengan G. F. Pijper, Beberapa Studi tentang Sejarah Islam di Indonesia 1900-1950, 146. 


\section{Struktur Epistemologi Tafsir Ayat Ash-Syiyam Karya M. Basiuni Imran}

Abdul Mustaqim menyebut bahwa bicara soal episteme tafsir maka bicara tentang tiga hal, yaitu hakikat, metodologi, dan validitas. Hakikat dan metodologi menyoal tentang apa itu tafsir dan penafsiran menurut penafsir, sumber apa yang dipakai, bagaimana prinsip penafsirannya, dan seperti apa metode praktis dalam memahami al-Qur'an - jadi ini tidak saja tentang metode seperti tahlili atau muqaran. ${ }^{64}$ Adapun validitas lebih pada di titik mana suatu tafsir boleh dibilang benar dan sah. ${ }^{65}$ Di bawah ini penulis akan menjelaskan bagaiamana rancang bangun penafsiran Basiuni Imran dalam karangannya ayat al-Siyam.

\section{Sumber atau asal-usul penafsiran}

Dari pengamatan penulis atas tafsir ayat al-Siyam, ada empat sumber dominan yang digunakan oleh Imran dalam menulis tafsirnya: al-Qur'an, riwayat atau hadis, pendapat ulama, dan rasionalitas dalam level tertentu. Dipakainya al-Qur'an sebagai sumber terlihat dari ketika Imran menjelaskan tentang taqwa. Bagi Imran taqwa memiliki tautan erat denga puasa. Pasalnya, keduanya sama-sama berporos pada sejauh mana seseorang memercayai kehadiran Tuhan di setiap detak nadinya. Ketika seseorang usai berhasil melakukan puasa dengan selalu melibatkan Tuhan sebagai sedenyar yang tidak bisa tidak mengawasinya, maka di waktu bersamaan yang bersangkutan sedang taqwa.

Bahasa lain dari perasaan diawasi ini, sebagai tambahan saja, oleh Foucault disebut sebagai peran panoptik. Ini bekerja seperti bagaimana para tahanan tidak berani untuk kabur dari penjara sebab ada panoptikon yang senantiasa mengawasi gerakgerik mereka. Taqwa adalah proses untuk menyituasikan diri sebagai tahanan yang seperti apa pun aktivitasnya adalah sedang diawasi oleh Tuhan.

${ }^{64}$ Lebih jelas baca Abu Hayy al-Farmawiy, Al-Bidayah fi at-Tafsir alMaudhu'iy (Beirut: Maktab al-Hadharah al-'Arabiyyah, 1977), 43

65 Abdul Mustaqim, Pergeseran Epistemologi Tafsir (Yogyakarta: Pustaka Pelajar, 2008), 134 dan Epistemolgi Tafsir Kontemporer (cet. I, Yogyakarta: LkiS, 2010), 289. 

(7):201. ${ }^{66}$

Sebagai justifikasi, ia merujuk pada surah al-A'raf

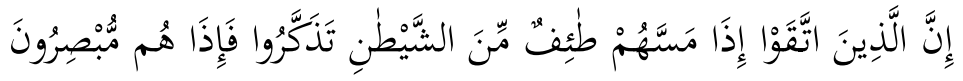

Artinya: Sesungguhnya orang-orang yang bertakwa bila mereka ditimpa was-was dari syaitan, mereka ingat kepada Allah, Maka ketika itu juga mereka melihat kesalahan-kesalahannya".

Justifikasi ini penulis menilainya sebagai sumber dari pandangan Imran tentang taqwa dalam al-Qur'an. Dilihat dari aras lain, model seperti ini bisa pula disebut sebagai munasabah al-ayat dalam titik yang agak berbeda. Dalam artian, semisal Imran memunculkan beberapa ayat lain selain 7:201, maka di situ bisa pula disituasikan sebagai penerapan munasabah al-ayat, di samping sebagai sumber penafsiran.

Kemudian contoh penafsiran Imran dengan sumber hadis atau riwayat adalah ketika ia menjelaskan tentang hakikat puasa dalam surah al-Baqarah (2):183-185. Imran menafsirkan beberapa ayat tersebut sebagai bukti berapa praktik puasa itu bukan saja tentang menahan makan dan minum atau puasa fisik, tetapi juga melibatkan puasa hati, jiwa, puasa batin. Maksud dari puasa batin, rohani, adalah sebisa mungkin berupaya untuk menghindarkan diri dari pikiran buruk dan tidak enggan untuk berhadapan dengan hawa nafsu. Hawa nafsu di sini lebih pada tindakan-tindakan yang bisa membuat orang lain tidak nyaman.

Dalam membangun argumentasinya ini, Imran merujk pada hadis bersumber dari Bukhari-Muslim, Imam Ahmad, dan ashab al-sunnah. Adalah hadis, "Siapa saja yang berpuasa dengan dasar keimanan dan keihlasan, maka Allah akan mengampuni dosanya tahun lalu." Jadi, menurut M. Basiuni Imran, seseorang tidak akan mendapat keutamaan tersebut jika hanya memuasakan fisik-tanpa roh-sebagaimana yang telah disebutkan di atas. ${ }^{67}$

1) Prinsip panafsiran

Prinsip di sini boleh disebut sebagai asumsi dasar yang dipakai Imran dalam melakukan aktivitas penafsiran. Penulis menemukan tiga prinsip yang dipakai Imran: deskripsi leksikallinguistik, konektivitas dan relasi teks, dan prinsip ilustrasi sebagai penjelas tafsir.

66 Muhammad Basiuni Imran, Tafsir Ayat Ash-Shiyam (Sambas: Kalimantan Barat, Manuskrip: 1936), 6.

${ }^{67}$ Muhammad Basiuni Imran, Tafsir Ayat Ash-Shiyam, 7. 
Deksripsi leksikal-linguistik cenderung kepada upaya pendefinisian atau analisis konsep - bisa juga bahasa - dari ayat yang ditafsirkan. Dalam tafsir Ayat al-Shiyam, M. Basiuni Imran memulai penafsirannya atas ayat puasa, al-Baqarah [2]:183, dengan mengemukakan makna baik etimologi atau pun terminologi dari kata saum.

Di aras etimologi, saum bermakna imsak atau "menahan". Adapun terminologinya bermakasud menahan diri dari perkara yang dapat membatalkan puasa, seperti makan, minum, dan bersenggama dari terbit fajar hingga terbenamnya fajar. ${ }^{68}$

Adapun prinsip konektivitas dan relasi teks yang dimaksud di sini adalah suatu model penafsiran dengan mengoneksikan suatu ayat dengan ayat lain dan ayat dengan hadis (riwayat) atau dengan pendapat ulama. Dalam tafsir Ayat al-Shiyam ini bisa dilihat dari bagaimana ketika menjelaskan satu ayat atau konsep tertentu ia tidak segan untuk memunculkan ayat lain sebagai pendukung argumentasi atau juga riwayat baik dari hadis maupun pendapat ulama. ${ }^{69}$

Terakhir, prinsip ilustrasi sebagai penjelas tafsir, orang bisa mengamatinya dari celah ketika Imran menjelaskan perumpaan mereka yang tidak berpuasa di bulan Ramadan dan mereka yang secara terang-terangan makan di tempat umum, di hadapan teman-temannya yang sedang menjalankan ibadah puasa. Imran mengibaratkan mereka ini dengan tikus yang mencuri makanan di rumah-rumah yang sepi dan dengan pecundang yang hanya berani minum air dengan dalih berenang. ${ }^{7}$

2) Metode, corak, dan pendekatan tafsir

Jika memakai kacamata bahwa metode al-Qur'an terdiri dari gaya tahlili, ijmali, muqarin, ijmali, dan maudlu' $i,{ }^{71}$ maka tafsir ayat al-Siyam Basiuni Imran termasuk dalam kategori ijmali. Kenyataan bahwa dalam menafsirkan al-Qur'an, Imran suka menggunakan bahasa yang ringkas, akrab, dan mudah dipahami serta hanya membidik aspek umumnya saja merupakan alasan mendasar mengapa penulis menyebutnya ijmali.

${ }^{68}$ Muhammad Basiuni Imran, Tafsir Ayat Ash-Shiyam, 2.

${ }^{69}$ Baca pada bagian sumber penafsiran di atas atau lihat Muhammad Basiuni Imran, Tafsir Ayat Ash-Shiyam, 7-8.

${ }^{70}$ Muhammad Basiuni Imran, Tafsir Ayat Ash-Shiyam, 9.

${ }^{71}$ Lebih jelas tentang metode-metode tafsir ini baca Abu Hayy alFarmawiy, Al-Bidayah fi at-Tafsir al-Maudhu'iy (Beirut: Maktab al-Hadharah al-'Arabiyyah, 1977), 43 
Di samping itu, isu yang dibidik Imran lebih pada apa yang sedang dibutuhkan masyarakatnya waktu itu. Kebutuhan di sini penting untuk dipahami sebagai tidak saja kebutuhan yang ada dalam benak masyarakat itu sendiri, tetapi juga kebutuhan yang ada di benak Imran atau apa yang bagi Imran dibutuhkan oleh masyarakat. Yang jelas, terlepas dari model kebutuhan tersebut, semua itu terporos pada membumikan nilai-nilai yang ada dalam al-Qur'an. Walhasil, di waktu bersamaan, oleh sebab ini pulalah tafsir Imran bercorak adabi-ijtima' $i$, jika meminjam klasifikasi Muhammad Abduh. ${ }^{72}$

Sebagai konsekuensi lanjutan — untuk tidak bilang satu paket-pendekatan yang dipakai Imran adalah pendekatan kontekstual. Kontekstual yang penulis maksud di sini adalah seperti yang dijelaskan oleh Islah Gusmian tentang pendekatan tafsir Nusantara yang terbelah dua, tekstual dan kontekstual. Adalah pendekatan yang menitikberatkan pada situasi tempat penafsir menulis tafsir. Situasi di sini tidak lain adalah masyarakat. Jadi, lantaran pertimbangan yang ada di benak Imran kala menafsirkan al-Qur'an condong ke kehidupan masyarakatnya yang tidak terlalu mengenal tafsir, maka pendekatan tafsirnya lebih ke kontekstual. Ini terlihat dari bagaimana ia memberi ilustrasi dan bahasa yang ringan.

Namun meski demikian, ini bukan berarti bahwa tafsirnya Imran melepaskan dirinya dari pendekatan tekstual seutuhnya. Di banyak bagian, Imran terlihat sibuk dengan analisis kebahasaan dan pendefinisian. Dalam menjelaskan satu konsep pun misalnya, ia sering memulainya dengan keterangan linguistik. Walhasil, melihat kenyataan yang demikian, penulis berpendapat bahwa pada dasarnya, klasifikasi di muka hanyalah soal titik tekan, tentang dominasi, bukan pengabaian sama sekali. Apa itu yang disebut tafsir kontekstual bagaimanapun melibatkan pendekatan tekstual, hanya saja porsinya tidak dominan. Beginilah yang penulis lihat dalam tafsir ayat al-Siyam karya Imran. 


\section{3) Validitas penafsiran}

Dalam kaitannya dengan sentuhan langsung masyarakat serta persilangan wacana yang seolah tak bertepi, tolok ukuran kebenaran sama sekali dibutuhkan. Tidak saja bagi konsumen pengetahuan, tetapi juga produsen itu sendiri. Di level kedua, tentu ini berjumbuh dengan penerimaan dan diseminasi.

Apa yang terjadi dari tafsir ayat al-Siyam karya Imran tidaklah berbeda. Sebab dia menulis tafsirnya adalah diperuntukkan untuk masyarakatnya yang tidak terlalu mengenal tafsir, dibanding dengan isu tarekat seperti dibahas di awal. Sejauh pembacaan atas karangan tafsir tersebut, penulis menemukan bahwa tolok ukur kebenaran yang dipakai Imran adalah pragmatis. Jika disejajarkan dengan teori koherensi dan korespondensi ${ }^{73}$ teori pragmatis lebih sesuai untuk disematkan kepada tafsir ayat al-Siyam.

Kebenaran pragmatis dekat dengan manfaat praktis. Yakni bagaimana sesuatu itu benar ketika ia memiliki efek praktis keseharian. Ketika misalnya ada dosen yang memberi semua siswanya nilai A dan lantas dengan nilai tersebut para siswa bisa lebih mudah mendapatkan kerja, maka apa yang dilakukan si dosen adalah benar. Kebenarannya terletak pada manfaat praktis kemudahan para siswa mendapatkan pekerjaan, sehingga kebenaran si dosen bisa disituasikan sebagai kebenaran pragmatis. Lebih jauh tentang kebenaran praktis ini, orang bisa menelusurinya lewat karya-karya Charles S. Peirce. ${ }^{74}$

${ }^{73}$ Baca Lihat Peter A. Angeles, Dictionary of Plolosophy (New York: Barner \& Noble Bokks Publisher, 1931), 297-299.

${ }^{74}$ Chales S. Peirce pada awalnya menyebut teorinya ini dengan "pragmatisme", dan kemudian mengubah mananya menjadi "pragmatisisme", ketika istilah pertama digunakan oleh John Dewey. F. C Schiller, dan William James untuk melebeli teori mereka yang sangat berbeda. Ricard R. Kirkhan, Theories of Truth: a Critical Introduction, terj. M. Khozin (Bandung: Nusa Media, 2008), 117. 
Berkenaan dengan ini-dengan lebih masuk ke rana tafsir al-Qur'an-Wandi Wendi Parwanto membagi cara pandang pragmatis sebagai tolok ukur kebenaran ini menadi dua bentuk: teoretis dan praktis. Pertama lebih pada adanya transmisi dan transformasi pengetahuan tafsir. Sejauh pengetahuan tafsir atau pemahaman seseorang (agen) yang didapatkan dari bacaannya atas tafsir masih mendapatkan momentumnya, maka di situlah kebenaran tafsir awal (yang dibaca agen) tidak lain adalah pragmatis. Pada bagian ini, posisi penafsir adalah sebagai agent of knowledge.

Kedua lebih pada membaca tafsir sama dengan menyelesaikan persoalan keseharian. Ini tentang inspirasi. Ketika seseorang membaca tafsir atau mendengar agen tertentu menjelaskan tafsir dan lantas dengan itu ia mampu menyelesaikan suatu persoalan, maka di situlah kebenaran tafsir tersebut adalah pragmatis. Jika yang pertama peran penafsir adalah sebagai agent of knowledge, maka di level kedua ini, ia sebagai agent of change. Manfaatnya praktis, tidak lagi teoretis diskursif.

Jika ditautkan dengan posisi tafsir ayat al-Siyam, maka aspek pragmatis dari tafsir tersebut bisa dilihat dari dua sisi, teoretis dan praktis. Tafsir ini, kala itu saja, diajarkan di beberapa tempat strategis dan diampu langsung oleh sang penulis seperti di Masjid Jami' Keraton Sambas setiap kamis sore dan di Sekolah Kulliyat al-Muballighin.

${ }^{75}$ Wendi Parwanto, Struktur Epistemologi Tafsir Surat Tujuh Karya Muhammad Basiuni Imran, Sambas, Kalimantan Barat, tesis (Fakultas Ushuluddin dan Pemikiran Islam, UIN Sunan Kalijaga, Yogyakarta, 2019), 199-200. 
Menurut Badran Hambali, ${ }^{76}$ sebagai tambahan, malah tafsir ayat al-Siyam digadang-gadang sebagai karya yang cukup berpengaruh dalam hubungannya dengan kajian al-Qur'an di sekitar Sambas dengan asumsi bahwa masyarakat Sambas kala itu masih buta tentang tafsir al-Qur'an — belum lagi jika ini dikaitkan dengan fakta bawa isu yang berkembang di masyarakat waktu itu adalah tarekat. $^{77}$

Adapun manfaat secara praktisnya tertambat pada keinginan masyarakat untuk memperbaiki niat serta model puasanya. Tafsir ayat al-Siyam membahas khusus tentang puasa. Ketika itu diajarkan, tentu diskusinya tidak jauh-jauh dari wacana puasa dan kemungkinan bisa juga menyentuh pada fakta puasa yang terjadi masa itu. Penulis tidak mendapatkan data yang cukup kuat untuk menyimpulkan sejauh mana pengaruh praktis dari tafsir di atas, tetapi secara umum, penulis berpendapat jika kajian tafsir puasa berbanding lurus-meski lentur-dengan praktik puasa di masyarakat Sambas.

${ }^{76}$ Badran Hambali adalah murid sekaligus anak dari Muhammad Basiuni Imran, yang merupakan saksi sejarah yang masih hidup sampai saat ini. Lihat Luqman Abdul Jabbar, "Tafsir Al-Qur'an Pertama di Kalimantan Barat (Studi Naskah Kuno Tafsir Surat Tujuh Karya Maharaja Imam Kerajaan Sambas 1883-1976 M)", 107.

${ }^{77}$ Luqman Abdul Jabbar, "Tafsir Al-Qur`an Pertama di Kalimantan Barat (Studi Naskah Kuno Tafsir Surat Tujuh Karya Maharaja Imam Kerajaan Sambas 1883-1976 M), 107; baca juga Wendi Parwanto, Struktur Epistemologi Tafsir Surat Tujuh Karya Muhammad Basiuni Imran, Sambas, Kalimantan Barat, 200. 


\section{E. Penutup}

Dari segenap penjelasan di atas, penulis menemukan bahwa episteme tafsir Muhammad Basiuni Imran dalam ayat alSiyam bisa diringkas menjadi tiga. Pertama, sumber tafsir berpulang pada riwayat baik hadis atau pun pendapat ulama, rasionalitas, dan al-Qur'an itu sendiri. Kedua, prinsip penafsirannya mencakup tiga gaya yakni linguistik, konektivitas, dan ilustrasi dengan metode ijmali, corak adabi-ijtima'i, serta pendekatannya kontekstual. Ketiga, validitasnya lebih ke ara pragmatis. Satu lagi: secara genealogi, Imran banyak terpengaruh oleh majalah al-Manar dan sosok Rasyid Rida sendiri, sehingga dalam mengajarkan puasa dari tafsir Ayat al-Siyam, Imran banyak menyuarakan pentingnya untuk mempertimbangkan sama sekali apa yang menjadi kandungan al-Qur'an — dan sunah di beberapa titik. 


\section{Daftar Pustaka}

Abdul Jabbar, Luqman. "Tafsir Al-Qur'an Pertama Di Kalimantan Barat (Studi Naskah Kuno Tafsir Surat Tujuh Karya Maharaja Imam Kerajaan Sambas 18831976M)", Jurnal Khatulistiwa: Journal of Islamic Studies, vol. 5, no. 1, 2015, 108.

Al-Farmawiy, Abu Hayy. Al-Bidayah fi at-Tafsir al-Maudhu'iy, Beirut: Maktab al-Hadharah al-'Arabiyyah, 1977.

Angeles, Peter A. Dictionary of Plolosophy, New York: Barnes \& Noble Books Publisher, 1931.

Asmuni, Muhammad Yusran. Pengantar Studi Pemikiran dan Gerakan Pembaharuan dalam Dunia Islam, Surabaya: al-Ikhlas, 1994.

Dhofier, Zamakhsyari. Tradisi Pesantren: Studi Atas Pendangan Hidup Kyai, Jakarta: LP3ES, 1990.

Effendy, Machrus. Riwayat Hidup dan Perjuangan Maharaja Imam Sambas, Jakarta : PT. Dian Kemilau, 1995.

Enayat, Hamid. Modern Islamic Political Thought, London: Mc Millan, 1982.

Fathurahman, Oman. "Jaringan Ulama : Pembaharuan dan Rekonsiliasi dan Tradisi Intelektual di Dunia MelayuIndonesia", Jurnal Studia Islamika, vol. 11, no. 2, 2004.

Fuad, Khairul. "Meretas Sastra Sufistik Kalimantan Barat Pramodern dan Modern", Jurnal Analisa, Vol. 19, No. $1,2012$.

G. F. Pijper, Beberapa Studi tentang Sejarah Islam di Indonesia 1900-1950, terj. Jakarta: UI Press, 1985.

Goldscmidt, Arthur. Biografical Dictionary of Modern Egypt, London: Lynne Rienner Publisher, 2000.

Gusmian, Islah. "Tafsir Al-Qur'an di Indonesia: Sejarah dan Dinamika", Jurnal Nun, Vol. 1, No. 1, 2015.

Islah. Khazanah Tafsir Indonesia: Dari Hermeneutika Hingga Ideologi, Yogyakarta: LkiS, 2013.

Hadenan dan Joni Tamkin, "Aspects of Economic Production in Malay Classical Literature According to Syeikh Daud Al-Fattani, Jurnal Al-Albab, Vol.1, No. 1, 2012.

Huda, Nor. Islam Nusantara: Sejarah Sosial Intelektual Islam Di Indonesia, Yogyakarta: Ruzz Media, 2013.

Ismail, Muis. Muhammad Basiuni Imran (Maha Raja Sambas), Pontianak: FISIP Universitas Tanjungpura. 1993. 
Kirkhan, Ricard R. Theories of Truth: a Critical Introduction, terj. M. Khozin, Bandung: Nusa Media, 2008.

M. Jaelani, "Sultan Muhammad Syafiuddin II: Pemimpin Karismatik dari Ujung Utara Borneo Barat", Jurnal Khatulistiwa, Vol. 4, No. 2, 2014.

Musa, Pabali H. Sejaah Kesultanan Sambas, Kalimantan Barat: Kajian Naskah Asal Raja-raja dan Silsilah Kerajaan Sambas, Pontianak: STAIN Press, 2003.

Mustaqim, Abdul. Pergeseran Epistemologi Tafsir, Yogyakarta: Pustaka Pelajar, 2008.

Mustaqim, Abdul. Epistemologi Tafsir Kontemporer, cet. I, Yogyakarta: LkiS, 2010.

Nasution, Harun, Pembaharuan Dalam Islam, Jakarta: Bulan Bintang, 1986.

Parwanto, Wendi. "Struktur Epistemologi Naskah Tafsir Surat Al-Fatihah Karya Muhammad Basiuni Imran, Sambas, Kalimantan Barat", Jurnal At-Tibyan, vol. 4, no. 1, 2019.

Parwanto, Wendi, "Struktur Epistemologi Tafsir Surat Tujuh Karya Muhammad Basiuni Imran, Sambas, Kalimantan Barat", Tesis, Fakultas Ushuluddin dan Pemikiran Islam, UIN Sunan Kalijaga, Yogyakarta, 2019.

Puslitbang Kemenag RI, Ensiklopedi Pemuka Agama Nusantara, cet. I, jilid. 3 \& 6, Jakarta : Puslitbang Kemenag RI, 2016.

Risa, "Islam dan Kerajaan Sambas Antara Abad XV-XVII: Studi Awal Tentang Islamisasi Sambas", Jurnal Khatulistiwa: Journal of Islamic Studies, Vol. 4, No. 2, 2014.

Salim, Moh. Haitami. dkk. Sejarah Kesultanan Sambas, Jakarta: Puslitbang Kemenag RI, 2011.

Suriadi, "Pendidikan Sufistik Tarekat Qadiriyyah wa Naqsabandiyyah: Kajian Atas Pemikiran Syeikh Ahmad Khatib Sambas", jurnal Khazanah, Vol. 15, No. 2, 2017.

Tafsir Surat Tujuh Karya Maharaja Imam Kerajaan Sambas 1883-1976 M), jurnal Khatulistiwa: Journal of Islamic Studies, Vol. 5, No. 1, 2015.

Tim Penelitian dan Penulisan Sejarah Sambas, Kabupaten Sambas: Sejarah Kesultanan dan Kepemerintahan Daerah, Pontianak: Taurus, t.th. 
Tafsir Ayat ash-Shiyam karya M. Basiuni Imran, Sambas, Kalimantan Barat: Studi Kritis atas Genealogi Pemiß̧iran dan Epistemologi Tafsir |

Wibowo, Basuki. "Otimalisasi Kraton Qadariyah dalam Pengembangan Pariwisata di Kota Pontianak Kalimantan Barat, dalam jurnal Edukasi, Vol. 1, No. $1,2014$.

Zulkifli, Sufism in Java: The Role of the Pesantren in the Maintenance of Sufism in Java, Laiden-Jakarta, INIS, 2002. 